Eguptian J. Anim. Prod. Vol. 33(1)(1996):1-9.

\title{
EFFECT OF SUPPLEMENTING RATIONS WITH BUFFERS ON THE YIELD, COMPOSITION AND PHYSICAL PROPERTIES OF BUFFALOES MILK DURING LACTATION PERIOD
}

\author{
M.A. El-Ashry ${ }^{1}$, S.M. Hamdy ${ }^{1}$, H.A. El-Alamy ${ }^{2}$ and A.M. Kholif ${ }^{2}$
}

1- Department of Animal Production, Faculty of Agriculture, University of Ain Shams, Cairo, Egypt, 2-Food Technology and Dairy Scince Department, National Research Centre, Giza, Egypt

\section{SUMMARY}

Twenty nine lactating buffaloes were used to assess the effect of supplementing diets with buffers on milk yield, milk composition and physical properties of milk. Animals were fed diets of $15 \%$ berseem hay, $15 \%$ rice straw and $70 \%$ concentrate feed mixture according to their nutritional requirements for energy and protein. The animals were grouped in four feeding treatments namely (I) control, (II) control + $1.5 \% \mathrm{NaHCO}_{3}$, (III) control $+2 \%$ dolomite and (IV) control $+3 \%$ calcium bentonite. The study was started at the end of the first week of lactation and extended to the $39^{\text {th }}$ week.

Sodium bicarbonate significantly $(P<0.05)$ increased mik fat content, milk pH and animal body weight, and decreased solids-not-fat, total protein, acidity and specific gravity contents of milk than control treatment. Dolomite treatment compared with control, significantly increased milk yield, F.C.M. yield and animal body weight, and decreased specific gravity of milk $(P<0.05)$. Bentonite treatment significantly decreased total protein, acidity and specific gravity contents of milk and animal body weight.

The buffer treatments significantly $(P<0.05)$ decreased zinc content of milk than control treatment. Milk contents of total phosphorus, sodium, potassium, magnesium, copper, iron and manganese were similar among treatments. Sodium bicarbonate supplementation increased milk calcium content than bentonite treatment .

Lactation period had a significant effect on milk yield, milk composition and animal body weight $(P<0.0001)$ except total phosphorus, calcium and iron contents. There was an interaction (treatment $x$ weeks of lactation) with milk $\mathrm{pH}$, acidity, calcium, sodium, potassium, magnesium and copper contents and animal body weight .

Keywords: Buffalo, ration, buffer supplimentation, milk

\section{INTRODUCTION}

The addition of buffers to dairy rations are being advocated to reduce the negative 
El-Ashry et al.

effects of high concentrate diets, during the last three decades. Sodium bicarbonate increased milk yield and its fat content (Erdman et al., 1980, Rogers et al., 1985, Coppock et al., 1986 and Woodford and Murphy, 1988 with dairy cows). However, Kertez et al. (1977), reported that milk yield declined by supplementing cows diets with $2 \%$ dolomite. Brings and Schultz (1969), Rindsig and Schultz (1970), Fisher and Mackay. (1983) and Zalewska et al. (1985) reported that milk yield and its fat content were increased when they supplemented dairy cows diets with bentonite. Fettman et al. (1984) revealed that $\mathrm{NaHCO}_{3}$ addition decreased milk sodium and potassium contents from 16.0 and $39.4 \mathrm{mg} /$ liter to 14.9 and $38.6 \mathrm{mg} /$ liter, respectively .

This experiment was conducted to compare the effectiveness of supplementing lactating buffaloes diets with sodium bicarbonate, dolomite or bentonite on the yield, composition and properties of milk during the first 39 weeks of lactation period.

\section{MATERIALS AND METHODS}

Twenty nine lactating buffaloes in the first week of lactation were blocked in groups of four by their weight and milk yield in the preceding lactation and assigned randomly to four dietary treatments in a 39-weeks feeding trial. They were selected from the buffaloes herd of Milk Replacer Research Center, Fac. of Agric., Ain Shams Univ. Mean body weights of animals in groups I, II, III and IV were $570,589,577$, and $566 \mathrm{~kg}$. respectively. Treatments were: (I) No supplemental buffers (7 animals), (II) $1.5 \%$ sodium bicarbonate ( 8 animals), (III) $2 \%$ dolomite ( 7 animals) and (IV) $3 \%$ bentonite ( 7 animals). The intended ratio of roughage to concentrate was 30:70. Berseem hay and rice straw (1:1) were used as a source of roughage, while concentrate feed mixture (CFM) used as the concentrate source (Table1). The offered feeds (twice daily) were assesed to cover the maintenance as well as the production requirements for each animal from strach value and digestable protein (Abou-Raya, 1967). The animals were drinked water (ad libitum) twice daily; which contains (in $\mathrm{mg} / \mathrm{liter}$ ) Mn, 0.05; Fe,0.12; $\mathrm{Zn}, 0.82 ; \mathrm{Cu}, 0.02 ; \mathrm{K}, 6.43 ; \mathrm{Mg}, 7.46 ; \mathrm{Na}, 25.18$ \& $\mathrm{Ca}, 40.0$.

Sampling and analysis of milk :

The animals were machine milked twice daily and milk yield was recorded. The animals were weighted and milk samples were collected once every two weeks for 15 weeks, then every four weeks till the end of lactation period.

The $\mathrm{pH}$ and acidity of milk were determined immediately after milking (Ling, 1963). Comosite samples (morning and evening) were analysed for milk fat, total solids, solids-not-fat, total protein and ash contents (Ling, 1963) and lactose content (Barnett and Tawab, 1957). The sodium, potassium, magnesium, calcium, iron, manganese, zinc and copper in milk samples were determined in the ash according to Jackson (1958) by using Atomic. Absorption Spectrophotometer (IL-S-12), while total phosphorus content was determined according to Troug and Meyer (1939).

The statistical analysis system (SAS) of Damon and Harvey, 1987, was used for least square of variance for repeated measures of milk weight, animal weight, milk composition and physical properties of milk. The model was:

$Y_{i j k}=\mu+T_{i}+e_{i k}+A_{j}+(T A)_{i j}+E_{i j k}$

where $\mu$ represented the mean, T treatment, A week of lactation, $T \times A$ treatment by week of lactation interaction, e eilik error $T$ which is animal within treatment, $E_{i j k}$ residual term. The Tukey procedure (HSD test) was used to test the significant between treatments means at $5 \%$ level. 
Egyptian J. Anim. Prod. (1996).

Table 1. Average chemical composition of experimental rations(Fresh matter basis)

\begin{tabular}{lrrrrcc}
\hline Items & \multicolumn{1}{c}{ CFM } & \multicolumn{1}{c}{$\mathrm{BH}$} & \multicolumn{1}{c}{$\mathrm{RS}$} & $\mathrm{NaHCO}_{3}$ & Dolomite & Bentonite \\
\hline Moisture\% & 9.48 & 11.13 & 8.68 & - & - & - \\
Dry matter \% & 90.52 & 88.87 & 91.32 & - & - & - \\
Ash\% & 9.07 & 11.82 & 17.83 & - & - & - \\
Organic matter \% & 81.45 & 77.05 & 73.50 & - & - & - \\
Crude protein \% & 16.92 & 13.72 & 2.94 & - & - & - \\
Ether extract \% & 4.28 & 2.37 & 1.94 & - & - & - \\
Crude fiber \% & 12.17 & 29.68 & 31.22 & - & - & - \\
Nitrogen-free- & & & & & & \\
extract\% & 48.08 & 31.28 & 37.40 & - & - & - \\
Minerals : & & & & & & \\
P\% & 0.59 & 0.16 & 0.07 & 0.02 & 0.02 & 0.09 \\
Ca \% & 0.57 & 1.68 & 0.75 & 1.12 & 17.80 & 4.00 \\
Na \% & 0.21 & 0.63 & 0.24 & 27.00 & 0.21 & 0.40 \\
K\% & 1.33 & 1.78 & 0.29 & 0.52 & 0.67 & 0.82 \\
Mg \% & 0.60 & 0.41 & 0.04 & 0.08 & 11.95 & 9.00 \\
Zn (mg/kg) & 19.00 & 21.00 & 11.00 & 52.00 & 23.00 & 20.00 \\
Cu (mg/kg) & 8.00 & 16.00 & 10.00 & 15.00 & 5.00 & 17.00 \\
Fe\% & 0.012 & 0.022 & 0.006 & 0.023 & 0.042 & 14.00 \\
Mn (mg/kg) & 74.00 & 30.00 & 11.00 & 29.00 & 56.00 & 19.00 \\
\hline & & & & & & \\
Starch Value* & 54.10 & 28.50 & 23.00 & - & - & - \\
Digestible & & & & & & \\
protein" & 10.20 & 8.60 & 0.00 & - & - & - \\
Milk value & 58.90 & 32.40 & 23.00 & - & - & - \\
\hline
\end{tabular}

* Average of 5 samples for each ingredient.

** These values are calculated using the nutrient digestibilities of Abou-Raya, (1967).

\section{RESULTS AND DISCUSSION}

Data on milk yield, animal body weight, milk composition and physical properties of buffaloes'milk are presented in Table (2). Milk yield and 4\% F.C.M. yield were significantly $(P>0.05)$ higher with dolomite supplementation than with other treatments. Sodium bicarbonte and bentonite supplementations, also, increased the yields of milk and F.C.M. than control treatments, but these increases were insignificant. Many published reportes indicated that milk yield increased with supplemmenting dairy cows' rations with 1.2 to $2.0 \% \mathrm{NaHCO}_{3}$ (Erdman el al., 1980 , Rogers et al., 1985, Coppock et al., 1986, and Woodford and Murphy, 1988) or with bentonite (Brins and Schultz, 1969, Rindsig and Schultz, 1970, Fisher and Mackay, 1983, Moate et al., 1985 and Zalewska ot al., 1985) due to increasing feed intake. Contrary to these results, Rogers ot al. (1982); DePeters ot al. (1984) and Vicini et al. (1988) (with $\mathrm{NaHCO}_{3}$ ); and Kertz ot al. 1977 (with dolomite) reported that milk yield declined when cows fed on the diet with $1.0-2.0 \% \mathrm{NaHCO}_{3}$ or $2.0 \%$ dolomite. However, Wheeler and Noller (1976) noted that dolomitic limestone buffer increased diet effeciency by improving the utilization of starch in the small intestine with a 
decline in the loss of energy as starch in faeces.

Table 2. Effect of supplementing rations with buffers on animal weight, milk yield, milk composition and some physical properties of buffaloes'milk, during 39 weeks of lactation period ${ }^{*}$

\begin{tabular}{lcccc}
\hline \multirow{2}{*}{ Component } & \multicolumn{4}{c}{ Means of treatments } \\
& Control & $\mathrm{NaHCO}_{3}$ & Dolomite & Bentonite \\
\hline No. of Samples & 80 & 92 & 85 & 85 \\
Animal weight (kg) (Ave.) & $579.78^{\mathrm{b}}$ & $597.71^{\mathrm{a}}$ & $581.79^{\mathrm{a}}$ & $571.46^{\mathrm{c}}$ \\
Milk yield (kg/day) & $5.71^{\mathrm{b}}$ & $5.84^{\mathrm{b}}$ & $6.54^{\mathrm{a}}$ & $6.24^{\mathrm{b}}$ \\
4\% Fat-corrected milk (Kg/day) & $8.30^{\mathrm{b}}$ & $8.68^{\mathrm{b}}$ & $9.60^{\mathrm{a}}$ & $8.84^{\mathrm{b}}$ \\
Fat \% & $7.16^{\mathrm{b}}$ & $7.46^{\mathrm{a}}$ & $7.16^{\mathrm{b}}$ & $7.04^{\mathrm{b}}$ \\
Total solids \% & $17.20^{\mathrm{ab}}$ & $17.30^{\mathrm{a}}$ & $17.20^{\mathrm{ab}}$ & $16.97^{\mathrm{b}}$ \\
Solids - not - fat \% & $10.04^{\mathrm{a}}$ & $9.83^{\mathrm{b}}$ & $10.01^{\mathrm{ab}}$ & $9.95^{\mathrm{ab}}$ \\
Total protein \% & $3.94^{\mathrm{a}}$ & $3.75^{\mathrm{b}}$ & $3.82^{\mathrm{ab}}$ & $3.68^{\mathrm{b}}$ \\
Lactose \% & 4.99 & 4.97 & 5.07 & 5.11 \\
Ash \% & 0.95 & 0.95 & 0.97 & 0.96 \\
Acidity \% & $0.22^{\mathrm{a}}$ & $0.21^{\mathrm{b}}$ & $0.22^{\mathrm{a}}$ & $0.20^{\mathrm{b}}$ \\
pH value & $6.68^{\mathrm{b}}$ & $6.71^{\mathrm{a}}$ & $6.69^{\mathrm{ab}}$ & $6.71^{\mathrm{a}}$ \\
Specific gravity (at $60^{\circ} \mathrm{F}$ ) & $1.03^{\mathrm{a}}$ & $1.03^{\mathrm{bc}}$ & $1.03^{\mathrm{b}}$ & $1.03^{\mathrm{a}}$ \\
Macro elements (mg/100 mi) & & & & \\
P & 94 & 97 & 95 & 100 \\
Ca & $187^{\mathrm{ab}}$ & $196^{\mathrm{a}}$ & $189^{\mathrm{ab}}$ & $186^{\mathrm{b}}$ \\
Na & 57 & 60 & 57 & 56 \\
K & 167 & 167 & 165 & 162 \\
Mg & 16 & 16 & 15 & 16 \\
Micro elements (mg/liter) : & & & & \\
Zn & $6.00^{\mathrm{a}}$ & $5.29^{\mathrm{b}}$ & $5.39^{\mathrm{b}}$ & $5.16^{\mathrm{b}}$ \\
Cu & 0.37 & 0.42 & 0.36 & 0.36 \\
Fe & 1.29 & 1.43 & 1.21 & 1.21 \\
Mn & 0.29 & 0.26 & 0.29 & 0.27 \\
\hline
\end{tabular}

Different superscripts; at the same raw, means significant differences $(P<0.05, a, b$ and c)

The live body weight was significantly higher $(\mathrm{P}<0.05)$ with $\mathrm{NaHCO}_{3}$ or dolomite supplementation than for control, which revealed a higher weight than bentonite supplementation, while changes in live body weight, at the end of lactation for treatments I, II, III, and IV, were 17.4, 17.7, 19.5, and $25.2 \mathrm{~g} / 100 \mathrm{~kg}$ live body weight; respectively. These results agreed with those reported for cows fed diet with $\mathrm{NaHCO}_{3}$ (Donker and Marx, 1980, Erdman et al., 1980 and Edward and Poole, 1983) or with bentonite (Rindsig and Schultz, 1970).

Milk fat content from the animals fed bicarbonate was higher than those for all treatments $(P<0.05)$, however, dolomite or bentonite supplementations did not affect milk fat content. Some workers have reported increasing in milk fat content with $\mathrm{NaHCO}_{3}$ addition to dairy cow diets (Erdmen et al., 1982a; Rogers et al., 1982 and Zhelev of al., 1984) or with bentonite addition (Brings and Schultz, 1969, Rindsig et 
Egyptian J. Anim. Prod. (1996).

al., 1969 and Rindsig and Schultz, 1970). However, Kertz et al. (1977), reported no changes in milk fat content with dolomite addition to cows' diets.

Sodium bicarbonate group showed the highest total solids content of milk, while control group showed the highest solids-not-fat and total protein contents of milk $(P<0.05)$.

These results agreed with those of Coppock et al. (1982 a\&b); DePeters et al. (1984), Vicini et al. (1988), however, Coppock et al. (1986) and West et al. (1986), showed an increase in milk total protein content when cows fed the diet with $1.5 \%$ $\mathrm{NaHCO}_{3}$. Fisher and Mackay (1983) reported a decrease in milk total protein conten with bentonite addition to cow diets.

Milk lactose and ash contents did not affected with buffer supplementation to the diet, but slightly increased $(P<0.05)$ with dolomite and bentonite supplementation. These results are in accordance with those reported by Okeke et al. (1983) and Boisclair et al. (1986) (with $\mathrm{NaHCO}_{3}$ ) and Fisher and Kackay (1983) (with bentonite) for lactose and Hadjipanayiotou (1982), (with $\mathrm{NaHCO}_{3}$ ) for ash content of milk.

The buffer supplementation, generally, increased milk pH and decreased the acidity and specific gravity of milk $(P<0,05)$. Lachmann $(1979)$ and Lachmann et al. (1982) concluded that the addition of $\mathrm{NaHCO}_{3}$ to diet decreased significantly the titeratable acidity in milk .

Milk zinc content was significantly $(\mathrm{P}<0.05)$ higher with control treatment than with buffer treatments. Also, $\mathrm{NaHCO}_{3}$ supplementation increased milk $\mathrm{Ca}$ content than bentonite supplementation $(P<0.05)$. Milk $P, N a, K, M g, C u, F e$ and $\mathrm{Mn}$ contents were not affected significantly by treatment. Fettman et al. (1984), found that milk $\mathrm{Na}$ and $K$ were not affected when they fed Holestein cows diet without or with $0.7 \%$ $\mathrm{NaHCO}_{3}$. The reasons of decreasing $\mathrm{Zn}$ content of buffaioes milk with buffer supplementation diets than control diet and increasing milk Ca content with $\mathrm{NaHCO}_{3}$ than bentonite supplementation diet are not clear.

Lactation period had a significant effect on milk yield, F.C.M., animal body weight, milk general composition and physical properties of milk $(P<0.0001)$; $N a(P=0.0069)$, $K(P=0.0881), M g(P=0.0001), C u(P=0.0734), Z n(P=0.0258)$ and $M n(P=0.0370)$, while milk $\mathrm{P}, \mathrm{Ca}$ and $\mathrm{Fe}$ did not differ significantly during lactation period. Abd ElSalam and El-Shibiny (1966), found that total P of buffaloes'milk fluctuated throughout lactation and appeared to exhibit no definite trend, while milk $\mathrm{Ca}, \mathrm{Mg}, \mathrm{Na}$ and $\mathrm{K}$ were generally affected by lactation period. Also, Dilanyan and Alsanyan (1967) showed that $\mathrm{Fe}, \mathrm{Mg}, \mathrm{Cu}$, and $\mathrm{Mn}$ contents of buffaloes milk were generally high during the first month of lactation, followed by a tendency to decrease with advancing lactation and increased somewhat towards the end of lactation. There were interactions (treatment $x$ weeks of lactation) with milk $\mathrm{pH}(\mathrm{P}=0.06)$, acidity percent $(P=0.02)$, animal body weight $(P=0.1) \mathrm{Ca}(P=0.085), \mathrm{Na}) \mathrm{P}=0.038, \mathrm{~K}$ $(P=0.048), M g \quad(P=0.029)$ and $\mathrm{Cu}(P=0.085)$, but not with $P, Z n, F e$ and $M n$ contents of buffaloes' milk.

\section{REFERENCES}

Abd El-Salam, M.H. and S. El-Shibiny, 1966. The chemical composition of buffalo milk. I. General composition. Indian. J. Dairy Sci., 19:151.

Abou-Raya, A.K., 1967. "Animal and Poultry Nutrition" 1st ed. Pub. Dar El-Maarif (Arabic Text Book).

Barrnett. A.J.G. and G. A.bd El-Tawab, 1957. Determination of lactose in milk and 
cheese. J. Sci. Food Agric., 8:437.

Brings, A.J.C. and L.H. Schultz, 1969. Effects of roughage type on added bentonite in maintaining fat test. J. Dairy Sci. $52: 465$.

Boisclair, Y., D.C. Grieve, J.B. Stone, O.B. Allan and G.K. Macleod, 1986. Effect of prepartum energy, body condition and sodium bicarbonate on production of cows

in early lactation. J. Dairy Sci. 69:2636.

Coppock, C.E., P.A. Grant; S.J. Protzer; A. Escobosa and T. E. Wehrly, 1982 a. Effect of varying dietary ratio of sodium and chloride on the responses of lacting dairy cows in hot weather. J. Dairy Sci. 65:552.

Coppock, C. E.; P.A. Grant; S.J. Protzer; D.A. Charles and A. Escobosa, 1982 b. Lactating dairy cow responses to dietary sodium, chloride and bicarbonate during hot weather. J. Dairy Sci., 65:566.

Coppock, C.E, G.T. Schelling, F.M. Pyers, J.W. West, J.M. Labore and C.E. Gates, 1986. A naturally occuring minerals as a buffer in the diet of lactating dairy cows. J. Dairy Sci., 69:111.

Damon, R.A. Jr. and W.R. Harvey, 1987. Experimental Design, Analysis of Variance, and Regression. Haper and Row. New York.

DePeters, E.J., A.H. Fredeen, D.L. Bath and N.E. Smith, 1984. Effect of sodium bicarbonate addition to alfalfa hay-based diets on digestibility of dietary fractions and rumen characteristics. J. Dairy Sci. 67:2344.

Dilanyan, Z. Kh. and E.S. Aslanyan, 1967. Trace elements in buffaloes' milk. Moloch. Prom. 28:31. C.F. DSA, 1967, 29:2475.

Donker, J.D. and C.D. Marx, 1980. Sodium bicarbonate in diets for milking Holstein cows. J. Dairy Sci., 63:931.

Edwards, S.A. and D.A. Poole, 1983. The effects of including sodium bicarbonate in the diet of dairy cows in early lactation. Animal Production, 37:183.

Erdman, R.A., R.L. Botts, R.W. Hemken and L.S. Bull, 1980. Effect of dietary sodium bicarbonate and magnesium oxide on production and physiology in early lactation. J. Dairy Sci. 63:923.

Erdman, R.A., L.W. Douglass, R.W. Hemken, T.H. the and L.M. Mann, 1982 a. Effects of sodium bicarbonate on palatability and voluntary intake of concentrates fed lactating dairy cows. J. Dairy Sci., 65:1647.

Fettman, M.J., L.E. Chase, J. Bentinck-Smith, C.E. Coppock and S.A. Zinn, 1984. Restricted dietary chloride with sodium bicarbonate supplementation for holstein cows in early lactation. J. Dairy Sci., $67: 1457$.

Fisher, L.J. and V.C. Mackay, 1983. The effect of sodium bicarbonate, sodium bicarbonte plus magnesium oxide or bentonite on the intake of corn silage by lactating cows. Canadian J. Anim, Sci. 63: 141.

Hadjipanayiotou, M., 1982. Effect of sodium bicarbonate and of roughage on milk yield and milk composition of goats and on rumen fermentation of sheep. J. Dairy Sci., 65 : 59 .

Jackson, M.L., 1958. Soil Chemical Analysis. Prentice-Hall, Inc., Englewood Clift, N.J., USA.

Kertz, A.F., L.F. Davidson, J.P. Jr. Everett, 1977. Influence of dietary buffers on milk production, faecal pH and faecal starch. J. Dairy Sci. $60: 116$ (Abstract).

Lachmann, G., 1979. Metabolic acidosis of diatary cow with particular reference to milk acidity (Soxhlet-Henkel method). Monatshefte dur Veterinar-medizin, 3446 , C.F. DSA, 1980, $42: 5983$. 
Lachmann, G., M. Schafer and D. Herenz, 1982. The SH acidity of milk from cows given supplements of sodium bicarbonate. Wissenschaftliche Zeit schrift der KarMarx-Universitait Leipzig. Mathematisch-Naturwisen Schaftlicire Reigne, 1982. 31 :424

Lling. ER., 1963. "Text Book of Dairy Chemistry" Vol. II. Practical Chapman and Hall, L.T.D., London. 3rd ed.

Moate, P.J., C.L. Rogers and T. Clarke, 1985. Effect of bentonite on the productivity of dairy cows fed a pasture diet. In R.B. Cumming (Ed) Recent advances in animal nutrition in Australia, Paper Nc. 15. C.F. DSA, 1986, 48: 6942.

Okeke, G.C., J.G. Buchanan-Smith and D.G. Grieve, 1983. Effect of sodium bicarbonate on rate of passage and degradation of scybean meal in postpartum dairy cows. J Dairy Sci. 66:1023.

Rindsing, R.B. and L.H. Schultz, 1970. Effect of bentonite on nitrogen and minera! balance and ration digestibility of highgrain rations fed to lactating dairy cows. U. Dairy Sci. 53 : 888 .

Rindsing, R.B., L.H. Schultz and C.E. Shook, 1969. Effects of the addition of bentonite to high-grain rations which decress milk fat percentage. J. Dairy Sci., 52:1770.

Rogers, J.A., C.L. Davis and J.H. Clark, 1982. Alternation of rumen fermentation, milk fat synthesis, and nutrient utilization with minerals salts in dairy cows. J. Dairy Sci., 65:677.

Rogers, J.A., L.D. Muller; C.L. Davis, W. Chalupa, D.S. Kronfeld, L.F. Karcher and K.R. Cummings, 1985. Response to dairy cows to sodium bicarbonate and limestone in early lactation. J. Dairy Sci. 68:646.

Troug, E. and Meyer, A.H., 1939. Improvement indeiness colorimetric method for phosphorus and arsenic. ind. Eng. Chem. Anal. Ed., 1:138

Vicini, J.L., W.S. Cohick, J.H. Clark, S.N. McCutcheon and D.E. Bauman, 1988. Effects of feed intake and sodium bicarbonate on milk production and Concentrations of hormones and metabolites in plasma of cows. J. Dairy Sci., 71:1232

West, J.W., C.E. Coppock; D.H. Nave and C.T. Schelling, 1982. Effects of potassium buffers on fed intake in lactaing dairy cows and on rumen fermentation in vivo and in vitro. J. Dairy Sci. 69:124.

Wheeler, W.E. and C.H. Noller, 1976. Limestone buffers in complete mixed rations for dairy cattle. J. Dairy Sci., 59:1788.

Woodford, S.T. and M.R. Murphy, 1988. Dietary alternation of particle breakdown and passage from the rumen in lactating dairy cattle. J. Dairy Sci., 71:687

Zalewska, E.; J. Krasucki and S. Cakala (1985). The trace elements $\mathrm{Cu}, \mathrm{Zn}, \mathrm{Fe}$, vitamine $\mathrm{B}-12$ and carotenoids, haematological indices $\mathrm{Hb}$ and $\mathrm{Ht}$, and milk production in cows given feed supplemented with bentonite. Medycyna Weterynaryina, 41:122, C.F. DSA, 1986, 48:126.

Zhelev, K., Ya. Profirov and N. Rusev, 1984. Effect of sodium bicarbonate on milk yield and percentage of fat in milk of cows of average productivity. Zhivotnov "dni Nauk.", 21:10. C.F. DSA, 1986, 48:125. 


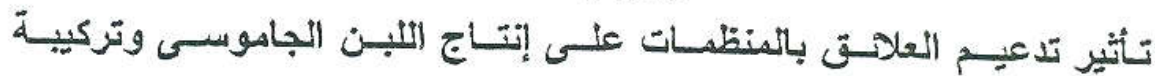

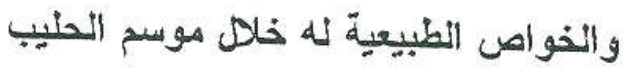

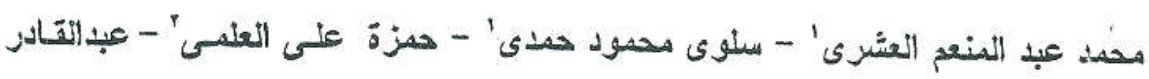

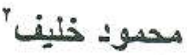

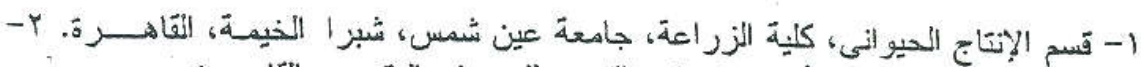

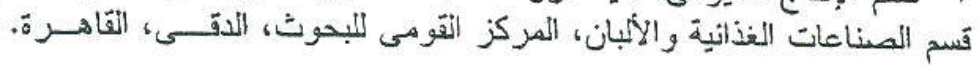

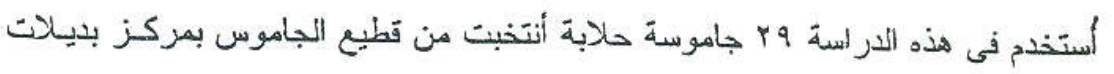

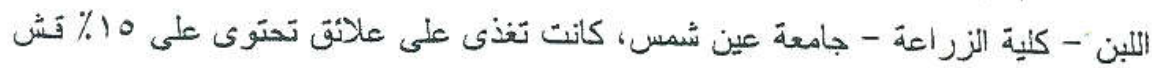

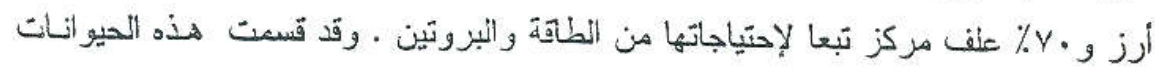

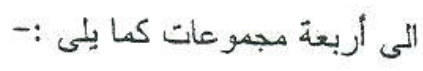

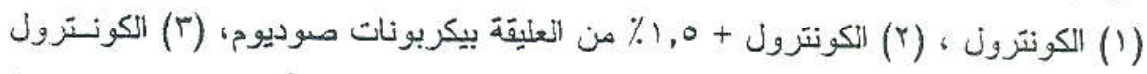

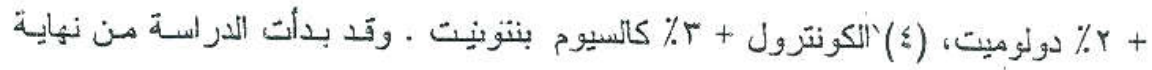
الأسبوع الأول وحتى الأسبوع ع وب من موسم الحليب.

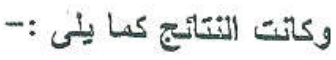

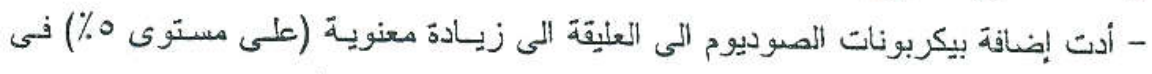

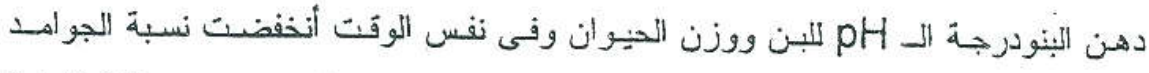

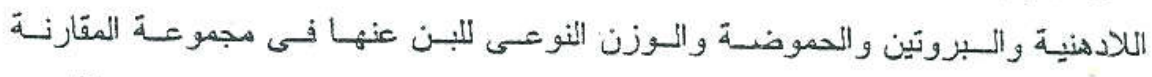

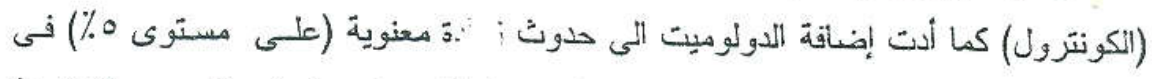

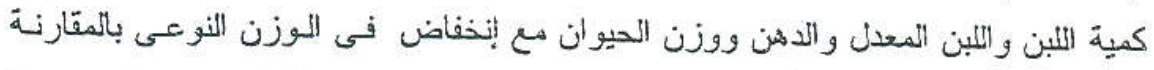

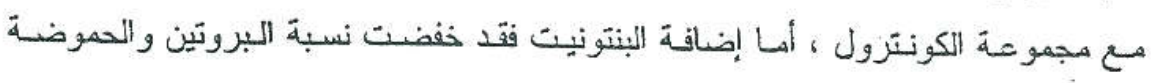

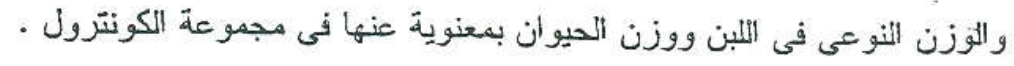

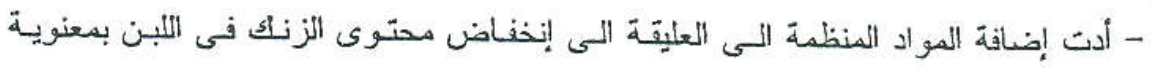

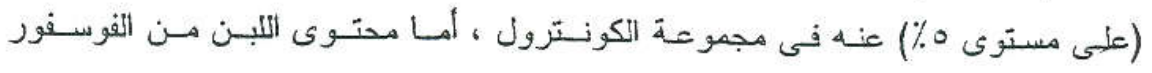

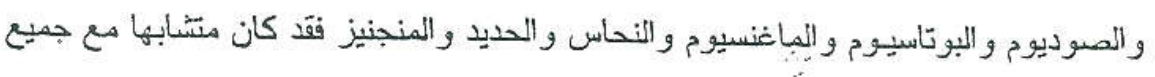




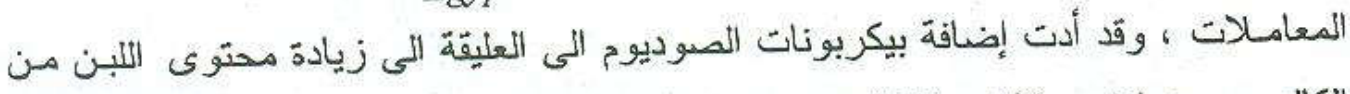

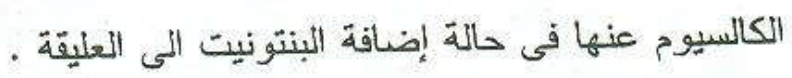

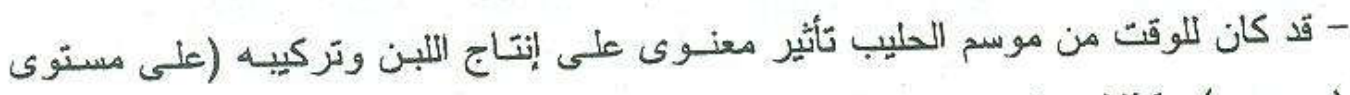

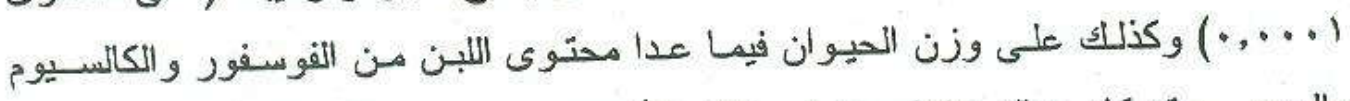

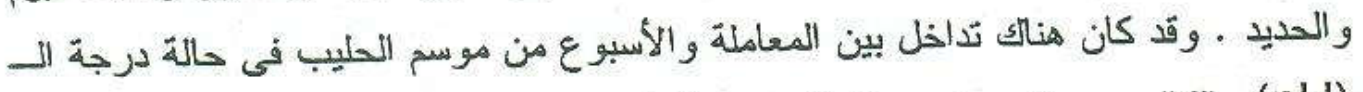

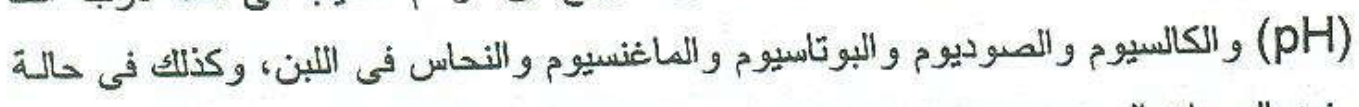

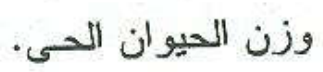

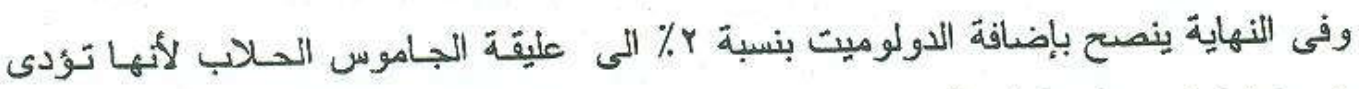

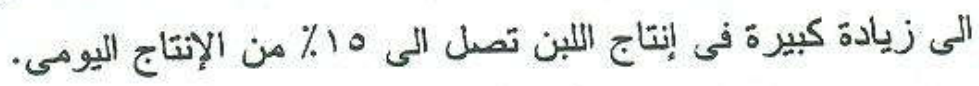

